\section{Blueprint for Revival?}

\author{
Jon Wynne-Tyson \\ Sussex, England
}

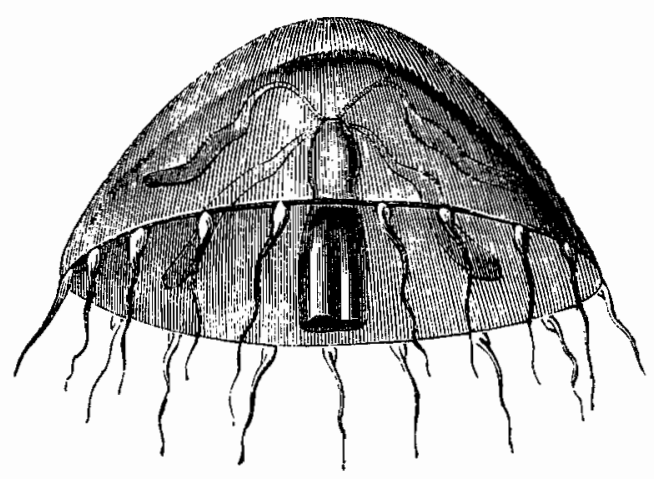

The fifteenth-century Dutch humanist Erasmusseldom quoted these days-saw the salvation of the world as lying in our individual endeavors, not in systems. "To make over the individual man is to make over the entire world."

I tried to explore this theme in my book The Civilised Alternative in 1972. As it brought a number of requests for a more spelled-out view of the form that alternative might take, I would like to suggest a few general pointers.

As a start, however, I must make clear that I do not go along with such as Godwin and Pelagius who, in their different ways, believed in the perfectibility of humanity. This is not because I side with the established church in its comfortable doctrine of Original Sin, but because human perfection is a contradiction in termsas Luther and Plato saw - especially in a world in which even God is often presented as a model falling well short of the sublime. Except in the Buddhist sense of disengagement, it is difficult to see how people can achieve perfection other than in the narrow practical or "task" sense. Perfection, it may be, is unavailable except through so high a degree of spiritual development as to bring about an individual outgrowing of the present limited concept of humankind. A leap, so to speak,

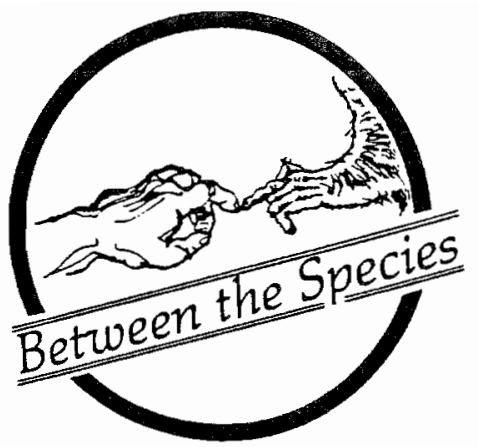

greater than that which produced so-called Homo sapiens. In this respect I share Bergson's antimechanistic view. There is an evolutionary impetus"an internal push that has carried life, by more and more complex forms, to higher and higher destinies." But this is taking us into waters too deep and too wide to be done justice here.

Nevertheless, all real improvement in our evolutionary state must depend upon a vision of the ideal, however far short we may fall of bringing it about. We must be skeptical of the reasoning of those who say, in effect, that because the bull's-eye is beyond our present skill we are wasting time hitting the outer rings. Negative and down-pulling reasoning is always on tap. Such thinking has to be resisted, just as the more perfect concept has to be invited, by drawing strength from the supra-rational. As Augustine said, later to be echoed by the Christian Scientists: "Evil has no positive nature; what we call evil is merely the lack of something that is good."2

In any discussion of an alternative world view it is tremendously easy to focus on the notion that merely cosmetic social change is all that is required. Our deficient educational system places inordinate faith in social engineering, technological skills, and the restructuring of existing systems according to the precepts of an essentially materialistic and acquisitive humanism.

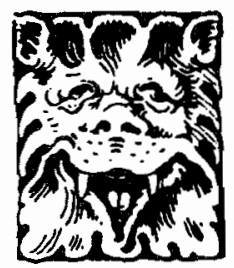


While such precepts are clearly inadequate, we must not deny their place. There must, of course, be some vision of the purely material structure, scale and balance of human society in any realistic projection of an alternative physical environment. I am far from alone in having presented some of the aspects of this projection and I would like to examine just five of them and try to expand them a little toward the goals they logically suggest and to underline their inescapable inter-relatedness.

1. What kind of world are we envisioning when we advocate deinstitutionalization and a greater respect for the concept of small-is-beautiful?

2. What will be the far-reaching consequences of the return many of us wish to see to the dietary pattern that best suits humankind's physiology?

3. What is the answer of those who seek unilateral or multi-national disarmament to the charge that such measures will expose rather than protect?

4. What are the remedial and preventive measures envisaged by those who abhor the violence of our times? (It is one thing to visualize a more humane system, another to re-educate the educators whose hands must hold the reins of progress.)

5. What, in followed-through and ultimate terms, are we saying when, conscious of the many problems created and exacerbated by an excess of our own species, we advocate a reduction and stabilization of human world population?

These objectives are sane, civilized, and inseparable from any realistic and humane blueprint for the future. But it is not enough that they remain static, compartmentalized visions of various aspects of the total problem; a rag-bag of unrelated, half-baked, if well-meaning egotrips for a handful of environmentalists who feel they should pay their intellectual respects to the future without taking the further step of understanding and facing the implications of those objectives.

It is, of course, perfectly true that these five objectives, and all that must logically proceed from their acceptance, are unlikely to be realized within our lifetimes and may be scores or even hundreds of years away. But if we do not agree, here and now, on some such long-term vision of the ideal, we have nothing to work toward. Without vision we shall continue to flounder in the brutal, selfish, endlessly "adjusting", and ultimately self-destructive chaos that our greeds, fears, and short-sightedness have created, and in the end we shall unquestionably either destroy ourselves and our environment or so alter our nature and circumstances for the worse that we shall have embarked upon the greatest exercise in the devolution of a species that the world has ever known.

So let us try to expand those headings just a little, at the same time indicating their inescapable interconnections.

1. The small-is-beautiful concept. What can this mean in global practice but internationally agreed deindustrialization and economic reappraisal, harnessing scientific and technological advance and priorities to the needs of a diminishing human world population (our fifth heading) that has been educated into a conviction of the smallis-beautiful ideal?

2. Already this concept-of a return to a dietary pattern more suited to mankind's physiologycan be seen as the corollary of any realistic acceptance that small is indeed beautiful, more workable and more humane. Just as deindustrialization and economic reappraisal are inseparable from acceptance of small-scale planning, so are the agricultural patterns of that new society. Agriculture will switch to promoting small-scale and organic methods consistent with, and alongside, a return to nothing less than a veganic dietary for all humankind.

\section{3, 4. Disarmament and the wider problem of civil} violence. Is it sane and practicable to visualize anything less far-reaching than an international peace force with an agreed program for the phasing-out of armed control to cope with the problems of violence that must continue in the long transitional period? Other measures must surely include the calling in, and prohibition of the manufacture, of arms of all kinds for civilian use. Linked to these positive measures will have to be a more realistic penal system in which offenders, instead of being hardened in their 
criminality by incarceration in crowded cells, will be required to contribute to social (and so their own) betterment through task force and community work.

5. The absolute necessity for a gradual return to an immensely reduced and stabilized human population. This fifth and final objective is perhaps the most vital material issue of all and deeply affects the other objectives and most of the problems and projects that will arise therefrom. Just as the small-is-beautiful concept must create smaller communities using a more responsible technology and subsisting by a more in-scale and humane agricultural pattern, so the less extravagant and more compassionate diet that results will indicate a gradual but purposive geographical redistribution of the earth's population, concentrating our species in areas whose climate most nearly meets our physiological needs.

That, then, is a very brief summary of five aspects of our projection (our blueprint, so to speak) for revival of a structure, system and values needed to reverse the present descent into chaos. I do not pretend, of course, that our species has ever before known such a form of Eden. But, certainly, we have known and lost some of its elements. It is these we must revive-the elements of scale, balance, space, compatible environment, simplicity, a wholly different ambition.

Under each heading a host of objections and doubts can quickly be assembled. To take only one, Western values are dominated by the belief that economic growth, scientific research and technological sophistication must expand without curb. To agitate for legislation to restrain the present scientific free-for-all would be futile and frustrating in the present megalomaniacal climate. The solution is long-term, dependent on the emergence of human beings whose education has replaced the arrogance of rationalism and expediency by the values of a compassionate environmentalism.

But there is no advantage in getting bogged down in diagnosis and prescription for each of the many ills by which society is afflicted. Once the broad basis for fundamental change has been laid, the ancillary problems will not prove insuperable.

The main difficulty with such an idealistic and distant vision as has been outlined is not that it is unattainable in material, structural or evolutionary terms, but that too many of us still take such a shortterm and self-centered view of life that we would prefer to be dead than sensible of what is best for succeeding generations. The will, not the means, is what is lacking.

Solution of this problem cannot, therefore, be democratic in the sense that it can be put to the vote of the entire human race. The bulk of our species, in its present lamentable state of development, would probably opt for a short life and a greedy one in preference to a pattern of self-restraint, empathy, compassion and evolutionary progress.

If this is so, what is the answer? I think it has to be that the seeds and the final structure for a fundamental change in human priorities will rest in the hands of a benevolent, infiltrating authoritarianism. Unthinking, fearful, self-centered, and inadequate men and women do not create structures or climates of thought that can benefit others. The inspiration for radical evolutionary change will emerge from a tiny nucleus of concerned human beings whose sincerity and sense of urgency have at least prompted agreement in all important particulars as to the means and the end. It must be the task of that nucleus, however inevitably imperfect its members, to meet and to persuade, directly and indirectly, the cultural, political, and educational leaders of the world. A nucleus of educators, in other words, operating in every field and at every level and age-group of society. (You, the reader, should you so wish, are to be counted as among those educators.)

This returns us to the point raised under the fourth of the five aspects of the projection I put forward earlier. It is of quite as much importance as the more tangible problem of reducing human numbers: the rigorous revision of our educational priorities.

I do not see how this revision can effectively be based on anything less than the realization that no social reform or political change can achieve lasting improvement unless our educators are concerned to replace the present obsession with power, violence, economic growth, technological progress, and nationalism by a wider, more compassionate, and hence more truly realistic concern with the essential community of humankind, and a less exploitative relationship with other forms of sentient life. But who, as has been said before, educates the educators? (I repeat: You! It is the how to which we should give further attention.) 
I accept that what I am trying to visualize honestly is a mammoth assignment. Yet is it anything like as great and hopeless as the futile efforts of imperfect human beings to avoid, by cosmetic titivation of a fundamentally sick and unworkable system, the consequences of their present addiction to the recipe for self-extinction?

I know I am taking a rough view of the stature, abilities, and idealism of humankind. There are those who may respond to the path of my reasoning with cries of "dictatorship" and "rubbish," or with sad, resigned smiles, preferring the status quo for the short-term gains they believe it has to offer. Some, too, will simply have given up in genuine despair. There is not much I can do about such critics except urge that all who accept the reasoning I have put forward-and I do not claim to have originated its ingredients-should concentrate on the positive task of achieving the desirable ends and not waste energy on trying to persuade the unpersuadable. We can no longer afford to play word games and create intellectual fantasies. Vision must lead to action.

What I am proposing is, I believe, the ultimate commonsense of a holistic philosophy. It is a philosophy that concerns - that must concern-not only the human species but also the circumstances and rights of nonhuman life. I believe this ingredient of holism to be as vital to the future as the more tangible priority of reducing human numbers in a finite world.

Richard Ryder spoke clearly on this subject in his contribution to the Humane Education Council's symposium at Sussex University. He abhorred (and I quote from his paper on the "Arrogance of Speciesism"):

mankind's almost universal assumption that the species Homo sapiens is different in kind from the other species and that is has "rights" or "interests" which the other sentient creatures can be denied. As the 1960s saw the Western cultures coming to grips with racism, and the 1970s found us tearing at the mental cobwebs of sexism, let us hope that the 1980s will see us extricating ourselves from the coils of speciesism. $^{3}$

I share with Richard Ryder, Tom Regan, Peter Singer, Jan Morris, Brigid Brophy, Catherine Roberts, Douglas Houghton, Stephen Clark and many others a particular concern about our treatment of other species. I do not see this as a separate or side issue to the evolution of humankind. On the contrary, I believe that no lasting improvement in our treatment of each other can come about until our species has been educated to accept and practice a more compassionate regard for all sentient life.

Realization of the indivisibility of violence and cruelty is not a recent phenomenon. I would go so far as to say that I know of no writer, philosopher, or scientist of any real stature who has not come out in defense of the weak, the innocent, and the helpless. Animals, birds, even fish-that whole great nation we contemptuously designate the sub-species-are of that kind. I am saying that no man or woman on the higher rungs of the creative ladder has failed to speak up in defense of, and to demand that compassion be shown to, other sentient life. Indeed, the point seems proved by my now established "Dictionary of Humane Thought": The Extended Circle. Joseph Addison, for instance, wrote:

True benevolence, or compassion, extends itself through the whole of existence and sympathizes with the distress of every creature capable of sensation.

Addison's vision has been shared by many civilizers of the past, including Pythagoras, Shelley, Jeremy Bentham, Shaw, Henry Salt, Schweitzer, Gandhi, Tolstoy, Dostoevsky, and was perhaps put best by Victor Hugo when he wrote:

It was first of all necessary to civilise man in relation to his fellow men. That task is already well-advanced and makes progress daily. But it is also necessary to civilise man in relation to nature. There, everything remains to be done...Philosophy has concerned itself but little with man beyond man, and has examined only superficially, almost with a smile of disdain, man's relationship with things, and with animals, which in his eyes are merely things. But are there not depths here for the thinker? Must one suppose oneself mad because one has the sentiment of universal pity in one's heart? Are there not certain laws of mysterious equity that pertain to the whole sum of things, and that are transgressed by the 
thoughtless, useless behavior of man to animals? ... For myself I believe that pity is a law like justice, and that kindness is a duty like uprightness. That which is weak has the right to the kindness and pity of that which is strong. Animals are weak because they are less intelligent. Let us therefore be kind and compassionate towards them. In the relations of man with the animals, with the flowers, with all the objects of creation, there is a whole great ethic [toute une grande morale] scarcely seen as yet, but which will eventually break through into the light and be the corollary and the complement to human ethics. ${ }^{4}$

But although I have not, I would hold, digressed in raising the fact of our responsibility to acknowledge the rights of other species, I must not give undue attention to any one aspect of our predicament. I have not even touched on some facets of our so-called civilized way of life-health, drugs, alcoholism, insanity, and so forth-for the good reason that these and many other social issues will respond almost automatically to adoption of the major measures I have listed.

Clearly the first step in educating the educators (who include ourselves) is to work individually to change the climate of thought in the world about us. Each of us is doing this every day of our lives, as much through our daily work and leisure activities as by writing and publishing books, giving lectures, or teaching in a classroom. Those who have connections in the corridors of power and persuasion-in the media, in politics, in areas where influence over corporate decisions can be exercised-may have particular opportunities, but none is necessarily of more value than the right word dropped at the right moment in the company of a receptive individual of no public prominence.

We simply must not underestimate the small pockets of resistance and conviction. I know too well how easy it is to feel that one's own small, lone voice in the wilderness is powerless to effect change. But this is patently untrue. Each grain of sand, each drop of water, makes a vital contribution to continent and ocean. Every dune and river is a collectivity. Our problem is not that we are failing to contribute but that our impatience to see results may invite despair. As nothing is going to be improved fundamentally through politics, and as the present debased concept of monarchy is unlikely to give way to philosopher kings or queens, there really is no alternative to "making over the individual."

As this point, surely, we must cease to worry over the material problems and the mechanistic frameworks for their solution, and turn instead to the comfort of philosophy and the lasting truths of spiritual values.

Consider for a moment that a thousand years ago no one would have believed in the possibility of the telephone, let alone of people reaching the moon. I approve of the telephone, by and large, although I do not approve of rushing round in space messing about with planets that have managed very well without us and should be left in innocence. Nevertheless, in terms of what we have been able to achieve at a material level, the telephone and space-craft are just two examples of this ability to attain the seemingly impossible.

None of our achievements would have been possible without acts or conditions of faith; without a refusal to accept the concept of impossibility; without a belief, that is to say, that the human mind can tune-in to some power or force that not only turns a seed into a flower, a grub into a butterfly, or a puling baby into the creator of a Beethoven symphony, but will supply both the inspiration and the means whereby humankind can realize almost any ambition that depends upon collaboration between heart and mind.

True, ambition can be for both good and evil, but it seems to be an evolutionary fact that evil aims contain their own seeds of destruction, whereas those that are benign and call upon the best that is in the spirit of humankind are in time recognized and preserved as models and inspiration for succeeding generations. I do not think there is any doubt about this, and I suggest it is one of the strongest (if inexplicable) pieces of evidence of the evolutionary process.

Our need is of patience. Our frustration comes from having glimpses of a better scheme of things and wanting it tomorrow. But just as the devolutionary tendencies have taken many years to reduce society to a state of shivering anticipation of nuclear war, civil violence, self-generated disease, institutionalized old age, and poverty amid plenty, so the reverse process will need time to establish a new and better order.

I do not propose to conclude with loose talk about God and destiny and humankind's supposed claim to a special and unique relationship with an anthropocentric deity. It is possible, I hold, to believe in God without claiming the least certainty about the facts of creation. Many people today have ceased to think of God in 
personalized terms, and hence of humankind as being in His image. Indeed, if we look at humankind as we are, as distinct from what we might be, to see ourselves here and now as being in God's image is to possess a very peculiar concept of the Deity. If God's image shines through the cold eyes of Margaret Thatcher, "Stormin" " Norman (Schwarzkopf), and Saddam Hussein, the Devil help us all. God, for many, is today something no more complicated than the essence of godliness, or goodness; a symbol for infinite mind, principle, love and truth rather than the instigator and humanized supervisor of our barbarous and brutal world; in short, a state of consciousness as yet no more than partially attained. Perhaps God, as Ernest Renan suggested, is what human beings must by their efforts help to bring into existence. ${ }^{5}$

For many younger people, a state of consciousness (or as they might put it, a state of awareness) is the nearest they come to claiming a religious sense. If that state of awareness impels its possessor to observe rules of conduct, and to hold values, that are in accordance with the underlying principles of the greatest religious systems, then I see it as of no less spiritual worth than the often less considered faith of those who take comfort from ritual, dogma and the doubtful theological speculation of those systems' spokespersons. It may be that the crumbling bricks and mortar of the established churches is evidence that the essence has been extracted and is being transmuted.

I believe that this essence is indeed living on in many of those who are seeking a gentler, more symbiotic and empathic relationship with their environment. The religion of our day might even be said to be a state of environmental sensitivity: a condition of mind and spirit less concerned with origins and speculations about the hereafter than with living by a set of principles in the faith that only by striving to practice the best one knows or feels will progress be made toward a wider and deeper understanding.

If this is a reasonable assessment of our present spiritual state, I do not believe that the problem of how we are to educate our educators will much longer frustrate us. Spiritual force is the greatest force in the world. It may have to work slowly, if only because of the rigid and inflexible systems people have erected to complicate their lives and imprison their souls. There is, I quite accept, the possibility that before that new spirit can have significant effect, humankind may have destroyed itself and its whole environment. If that is to be, then perhaps it is no less than we have earned by our stubborn indifference to karmic law. But here one is speculating. The misery we have already brought upon ourselves may be retribution enough. Time alone will tell. For the present I am not in too much despair. I have lived for long enough to detect and take heart from the proofs of progress. This is a blessing denied the young, who see the world only as it is and have no memory of when it was in some respects worse.

I certainly do not despair of the young. I see in my own children's contemporaries a common sense, an intuition and an idealism that was undoubtedly less apparent in their parents' generation. They are already making their contribution to educating the future, and if we believe that spiritual truth is the greatest power on earth we can contribute most by strengthening our own faith in the young and in their future.

I may have tried to cover, or at least touch upon, too wide a field. But there is, as I say, a great need to begin to correlate and amplify toward their logical conclusions and a general solution all these separate concerns and partial visions. This is all I have tried to do in this brief contribution.

What I feel is important is that when we turn our attention to the specific aspects on which our individual knowledge or intuition compels us to concentrate, we should try to keep always at the back of our minds the holistic vision: the vision not merely of our answers to the particular problem we have set ourselves, but of the ultimate structural and spiritual model of which our separate contributions are small but vital components.

I do not believe in the certain salvation of humankind. I do not believe that telling beads and confessing sins are what is required of an evolutionary species, any more than I believe that the species is capable of perfection within the limitations of human existence. To shed the notion that somehow economic and technological growth plus political musical-chairs can stand in for evolutionary progress is the essential prerequisite to setting about the priorities. It is the striving toward perfection that matters, not its realization. As E. F. Schumacher has written:

The maps produced by modern materialistic scientism leave all the questions that really matter unanswered. More than that, they do not even show a way to a possible answer: they deny the validity of the questions. The situation was disparate enough in my youth 
half a century ago; it is even worse now because the ever more rigorous application of the scientific method to all subjects and disciplines has destroyed even the last remnants of ancient wisdom-at least in the Western world. It is being loudly proclaimed in the name of scientific objectivity, that "values and meanings are nothing but defence mechanisms and reaction formations" (Frankl, Beyond Reductionism, 1969), that man is "nothing but a complex biochemical mechanism powered by a combustion system which energises computers with prodigious storage facilities for retaining encoded information" (ibid). Sigmund Freud even assured us that "this alone I know with certainty, namely that men's value judgments are guided absolutely by their desire for happiness, and are therefore merely an attempt to bolster up their illusions by arguments" (quoted by M. Polanyi, Personal Knowledge, 1958).

How is anyone to resist the pressure of such statements, made in the name of objective science, unless, like Maurice Nicoll, he suddenly receives "this inner revelation" of knowing that men, however learned they might be, who say such things, know nothing about anything that really matters? People are asking for bread and they are being given stones. They beg for advice about what they should do "to be saved," and they are told that the idea of salvation has no intelligible content and is nothing but an infantile neurosis. They long for guidance on how to live as responsible human beings, and they are told that they are machines, like computers, without free will and therefore without responsibility.

Man's happiness is to move higher, to develop his highest faculties, to gain knowledge of the higher and highest things and, if possible, to "see God."

Schumacher, in common with every serious seeking mind, saw that it is impossible for any civilization to survive without a faith in meanings and values transcending the utilitarianism of comfort and survival-in other words, without a religious faith. Lacking it, we shall never realize that greatly improved and distant scheme of things that is the only raison d' etre and comfort to be drawn from calm contemplation of this grossly imperfect world.

\section{Notes}

${ }^{1}$ Henri Bergson, Creative Evolution. (trans A. Mitchell) (London: Macmillan, 1919).

${ }^{2}$ St. Augustine, The City of God. (trans G. G. Walsh) (London: Heinemann, 1958).

${ }^{3}$ In D. Paterson (ed.), Humane Education-a Symposium (Humane Education Council, 1981). p. 5.

${ }^{4}$ Victor Hugo, "Alpes et Pyrenées." Quoted in C. Renouvier, Victor Hugo le philosophe (Paris: 1900).

${ }^{5}$ Ernest Renan, Dialogues et fragments philosophiques (Paris: 1876).

${ }^{6}$ E. F. Schumacher, A Guide for the Perplexed (London: Jonathan Cape, 1977), pp. 14-15, 22.

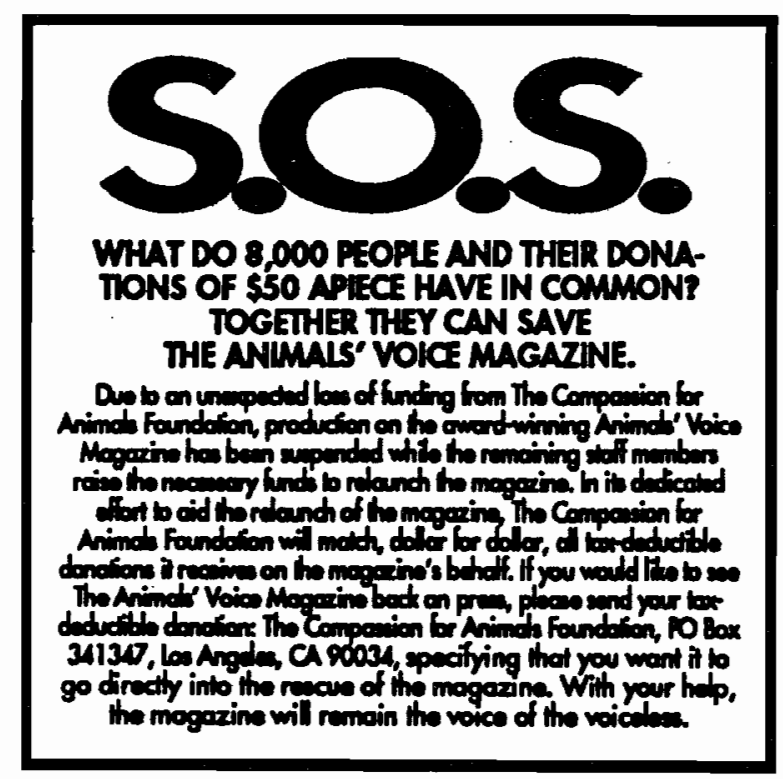

